\title{
Glutathione Peroxidase-like Activities of Oxygen-Containing Diselenides
}

\author{
Thomas Wirth*
}

Institut für Organische Chemie der Universität Basel, St. Johanns-Ring 19, CH - 4056 Basel, Switzerland Tel. +41 61267 1146, Fax +41 61267 1105, Email wirth@ubaclu.unibas.ch

Received: 9 June 1998 / 13 July 1998 / Published: 27 July 1998

\begin{abstract}
Various diselenides $1-\mathbf{8}$ have been examined with respect to their glutathione peroxidase-like activities (GPx-activities) as an index of their antioxidant properties. The glutathione oxidase activities of these compounds have also been reviewed reflecting the pro-oxidant properties (GOx-activities) and could be used as an index of cell toxicity. Based on a qualitative structure-activity relationship some trends are suggested.
\end{abstract}

Keywords: Antioxidants; diselenides; glutatione oxidase; glutathione peroxidase; oxidative stress.

\section{Introduction}

Glutathione peroxidases (GPx) are antioxidant selenoenzymes protecting various organisms from oxidative stresses by catalyzing the reduction of hydroperoxides at the expense of glutathione [1]. After the discovery of selenium as selenocysteine (SeCys) in the active site of GPx [2], there has been a growing interest in the biochemistry of selenium. Other selenium-containing enzymes have been identified recently [3]. X-ray diffraction studies on GPx have shown that the two nitrogen atoms of Gln-70 and Trp-148 are located very near the selenium atom of SeCys-35 in the active site [4]. Based on this observation, various organoselenium compounds containing other heteroatoms have been synthesized to mimic the active site of GPx [5]. Mostly nitrogen containing selenium compounds have been investigated which can act as GPx mimics [6]. Recent simulations of the catalytic cycle of glutathione peroxidase by molecular modelling stress again the importance of heteroatoms near the selenium [7]. It is known from several investigations, that heteroatoms in an 1,3-distance to selenium can interact with selenium in forming pseudo hypervalent compounds [8]. Some of the compounds studied are diselenides which can catalyze the reduction of hydroperoxides by thiols [5b,9] (Scheme 1).

$$
\mathrm{ROOH}+2 \mathrm{R}^{\prime} \mathrm{SH} \stackrel{\text { cat. }\left(\mathrm{R}^{\prime \prime S e}\right)_{2}}{\longrightarrow} \mathrm{ROH}+\mathrm{H}_{2} \mathrm{O}+\mathrm{R}^{\prime} \mathrm{SSR}^{\prime}
$$

Scheme 1. Catalytic reduction of hydroperoxides. 


\section{Results and Discussion}

In the course of our studies concerning asymmetric reactions with chiral selenium electrophiles, a series of new diselenides containing an oxygen as heteroatom in close proximity to selenium were prepared [10]. The asymmetric induction observed was investigated in detail and is due to an interaction between the oxygen and the selenium [11]. We were interested to evaluate the GPx-like activity for the oxygen-containing diselenides $1-8$ (Figure 1). The antioxidant properties (GPx activities) and the pro-oxidant properties (glutathione oxidase [GOx] activities) were investigated (Table 1).<smiles>[R]c1cccc(C(O)CC)c1[Se]</smiles>

$1 \mathrm{R}=\mathrm{H}$

$2 \mathrm{R}=\mathrm{Me}$

$3 \mathrm{R}=\mathrm{CF}_{3}$

$4 \mathrm{R}=\mathrm{CH}(\mathrm{OH}) \mathrm{Et}$<smiles>CCC(OC)c1ccccc1S(=O)(=O)OC</smiles>

5<smiles>O=S(=O)(O)c1cccc2c1C(O)CCC2</smiles>

6<smiles>CC(O)Cc1ccccc1S(=O)(=O)[O-]</smiles>

7<smiles>COc1ccc(S(=O)(=O)c2ccccc2)cc1</smiles>

8

Figure 1. Diselenides prepared and investigated.

Table 1. GPx and GOx activities of diselenides $\mathbf{1}-\mathbf{8}$.

\begin{tabular}{cccc}
\hline Diselenide & $\begin{array}{c}\text { GPx activities } \\
(20 \mu \mathrm{M} \mathrm{Se}-E q u i v a l e n t s) \\
{\left[\mathrm{nmol} \mathrm{of} \mathrm{NADPH} \bullet \mathrm{min}^{-1}\right]}\end{array}$ & $\begin{array}{c}\text { GPx activities } \\
(20 \mu \mathrm{M} \mathrm{Se-Equivalents}) \\
{\left[\mathrm{nmol} \mathrm{of} \mathrm{NADPH} \bullet \mathrm{min}^{-1}\right]} \\
200 \mu \mathrm{M} \text { - } \mathrm{BuOOH}\end{array}$ & $\begin{array}{c}\text { GOx activities } \\
(20 \mu \mathrm{M} \text { Se-Equivalents }) \\
{\left[\mathrm{nmol} \mathrm{of} \mathrm{NADPH} \mathrm{H}_{2} \mathrm{O}_{2}{ }^{-1}\right]}\end{array}$ \\
\hline $\mathbf{1}$ & 26.6 & 13.9 & 1.1 \\
$\mathbf{2}$ & 20.2 & 13.0 & 0.3 \\
$\mathbf{3}$ & 8.7 & 4.7 & $0 \mathrm{a})$ \\
$\mathbf{4}$ & 18.8 & 9.5 & 0.3 \\
$\mathbf{5}$ & 14.5 & 7.8 & 0.2 \\
$\mathbf{6}$ & 27.5 & 14.8 & 1.0 \\
$\mathbf{7}$ & 17.9 & 11.5 & 0.4 \\
$\mathbf{8}$ & 30.2 & 17.7 & 0.9 \\
\hline
\end{tabular}

a) not detectable.

The diselenides were prepared by short synthetic sequences as described [10]. The GPx activities were measured with the protocol of Paglia et al. using the glutathione reductase coupled assay with either hydrogen peroxide or tert-butyl hydroperoxide as oxidant [12]. The diselenides were tested at $20 \mu \mathrm{M}$ selenium equivatents. The
GOx activites were derived from the kinetics of NADPH oxidation without peroxides in air-saturated buffer with catalase. In the presence of thiol, oxygen is reduced by the diselenides in an one-electron transfer process leading to the production of reactive oxygen species. The GOx 
activites are therefore an estimation of the cytotoxicity of these molecules. The results are summarized in the Table.

As it can be seen from the Table, all diselenides investigated showed GPx-like activities. The most active compounds are the molecules $\mathbf{1}, \mathbf{6}$, and $\mathbf{8}$. All bis-ortho substituted diselenides $(\mathbf{2}-\mathbf{4})$ showed significantly lower activity which could be attributed to steric hindrance. As shown with compound $\mathbf{3}$, an electron withdrawing substituent seems detrimental for the GPx-like activity, which parallels the decrease of electron density at the selenium atom. The opposite effect is obtained in compound 8, which shows the highest activity of this series. Interestingly, diselenide $\mathbf{5}$ with a methoxy group instead of a hydroxy group exhibits only $50 \%$ of the activity of compound 1. Finally, the lower activity of compound 7 could indicate a less favourable interaction between oxygen and selenium. The pro-oxidant (GOx) activities of all diselenides tested are very low. Comparing the measured values for the GOx activities, the compounds $\mathbf{1}, \mathbf{6}$, and $\mathbf{8}$ should be more cytotoxic than the other diselenides investigated.

\section{Conclusions}

From the data obtained, it seems that compound $\mathbf{2}$ might be a good candidate regarding the glutathione peroxidase (GPx) activity as well as the glutathione oxidase (GOx) activity. Further investigations would be necessary to conclude on the cytoprotective effect of the diselenides investigated, although some trends can already be seen from the results described herein.

Acknowledgements: This work was supported by the Schweizer Nationalfonds and by the Treubel Fonds (scholarship for T. W.). I thank G. Fragale for the preparation of $\mathbf{3}$ and $\mathbf{6}$ and Prof. B. Giese for continuous support. I thank J.-C. Yadan and I. Erdelmeier, Oxis International S.A. (Bonneuil-sur-Marne, France), for the measurement of the GPx and GOx activities and for many fruitful and stimulating discussions.

\section{References and Notes}

1. Reviews: a) Stadtman, T. C. J. Biol. Chem. 1991, 266, 16257-16260. b) Ursini, F. In Oxidative Processes and Antioxidants; Paoletti, R., Ed.; Raven Press: New York, 1994; pp 25-31.

2. a) Rotruck, J. T.; Pope, A. L.; Ganther, H. E.; Swanson, A. B.; Hafeman, D. G.; Hoekstra, W. G. Science 1973, 179, 588-590. b) Flohé, L.; Gunzler, W. A.; Schock, H. H. FEBS Lett. 1973, 32, 132-134.
3. a) Berry, M. J.; Banu, L.; Larsen, P. R. Nature 1991, 349, 438-440. b) Boyington, J. C.; Gladyshev, V. N.; Khangulov, S. V.; Stadtman, T. C.; Sun, P. D. Science 1997, 275, 1305-1308.

4. a) Ladenstein, R.; Epp, O.; Bartels, K.; Jones, A.; Huber, R.; Wendel, A. J. Mol. Biol. 1979, 134, 199218. b) Epp, O.; Ladenstein, R.; Wendel, A. Eur. J. Biochem. 1983, 133, 51-69.

5. a) Reich, H. J.; Jasperse, C. P. J. Am. Chem. Soc. 1987, 109, 5549-5551. b) Wilson, S. R.; Zucker, P. A.; Huang, R.-R. C.; Spector, A. J. Am. Chem. Soc. 1989, 111, 5936-5939. c) Iwaoka, M.; Tomoda, S. J. Am. Chem. Soc. 1994, 116, 2557-2561. d) Engman, L.; Andersson, C.; Morgenstern, R.; Cotgreave, I. A.; Andersson, C.-M.; Hallberg, A. Tetrahedron 1994, 50, 2929-2938. e) Chaudière, J.; Yadan, J.-C.; Erdelmeier, I.; Tailhan-Lomont, C.; Moutet, M. In Oxidative Processes and Antioxidants; Paoletti, R., Ed.; Raven Press: New York, 1994; pp 165-184.

6. a) Chaudière, J.; Moutet, M.; d'Alessio, P. C. R. Soc. Biol. 1995, 189, 861-882. b) Sies, H. Free Rad. Biol. Med. 1993, 14, 313-323.

7. Aumann, K.-D.; Bedorf, N.; Brigelius-Flohé, R.; Schomburg, D.; Flohé, L. Biomed. Environ. Sci. 1997, 10, 136-155.

8. Hargittai, I.; Rozsondai, B. In The Chemistry of Organic Selenium and Tellurium Compounds; Patai, S., Ed.; Wiley: Chichester, U.K., 1986, Vol. 1, pp 63-155.

9. a) Galet, V.; Bernier, J.; Henichart, J.; Lesieur, D.; Abadie, C.; Rochette, L.; Lindenbaum, A.; Chalas, J.; Renaud de la Faverie, J.; Pfeiffer, B.; Renard, P. J. Med. Chem. 1994, 37, 2903-2911. b) Mlochowski, J.; Giurg, M.; Kubicz, E.; Said, S. B. Synth. Commun. 1996, 26, 291-300. c) Back, T. G.; Dyck, B. P. J. Am. Chem. Soc. 1997, 119, 2079-2083.

10. Compounds 1-7: Wirth, T.; Fragale, G. Chem. Eur. J. 1997, 3, 1894-1902. Compound 8: Uemura, S.; Takahashi, H.; Ohe, K.; Sugita, N. J. Organomet. Chem. 1989, 361, 63-72.

11. Wirth, T.; Fragale, G.; Spichty, M. J. Am. Chem. Soc. 1998, 120, 3376-3381.

12. Paglia, D. E.; Valentine, W. N. J. Lab. Clin. Med. 1967, 70, 158-169.

Samples Availability: Available from the author. 